\title{
Herpes zoster ophthalmicus: is the globe involved?
}

\author{
Judit Szent-Ivanyi, ${ }^{1}$ Ali S Hassan, ${ }^{2}$ Masoud Teimory ${ }^{2}$
}

${ }^{1}$ Kings College, London, UK ${ }^{2}$ Department of Ophthalmology, Worthing Hospital, Worthing, West Sussex, UK

\section{Correspondence to} Dr Ali S Hassan, alishassan@doctors.org.uk

Accepted 31 March 2014

\section{(a) CrossMark}

To cite: Szent-Ivanyi J, Hassan AS, Teimory M. BMJ Case Rep Published online: [please include Day Month Year] doi:10.1136/bcr-2014204566

\section{DESCRIPTION}

An 87-year-old immunocompetent man presented with left-sided herpes zoster ophthalmicus (HZO). His symptoms began with facial dysaesthesia, before erupting into a vesicular rash affecting the left forehead, periorbital skin and nose. The tip of the nose was not involved (figure 1). HZO occurs due to reactivation of latent varicella-zoster virus (VZV) in the trigeminal ganglion. The reactivated virus has a predilection for the ophthalmic division of the trigeminal nerve. ${ }^{1}$ Reactivation is more common in immunocompromised persons and in the elderly. ${ }^{2}$

The ophthalmic division of the trigeminal nerve divides into three main branches: the frontal nerve, the lacrimal nerve and the nasociliary nerve. The nasociliary branch innervates the ciliary body, iris, cornea and conjunctiva. Its terminal branch is the anterior ethmoidal nerve, which innervates the sides of the tip of the nose (alae nasae) via the external nasal nerve.

Hutchinson ${ }^{3}$ observed that ocular involvement is more commonly seen if the HZO rash involves the alae nasae. Up to $85 \%$ of such cases may develop ocular involvement ${ }^{1}$; all such patients should have an urgent ophthalmic examination. ${ }^{4}$ If Hutchinson's sign is absent ocular involvement is less likely, however can still occur and is likely to be present if the patient reports reduced vision, eye pain or photophobia. Additionally, reduced corneal sensa-

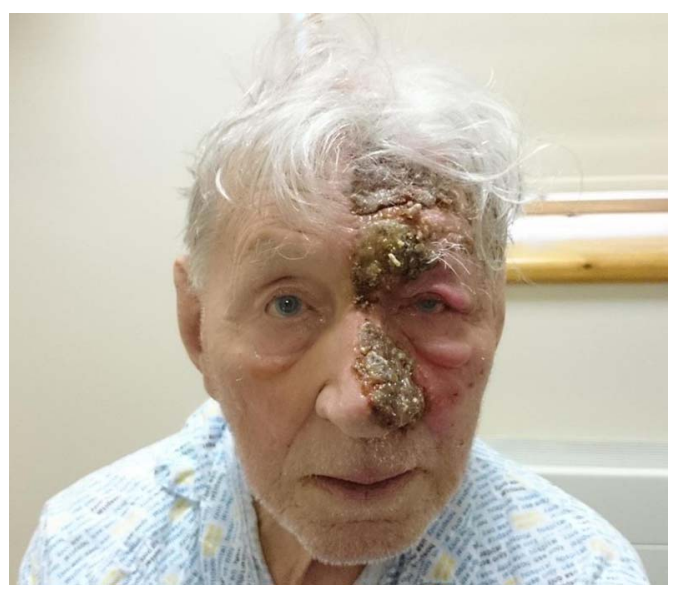

Figure 1 A vesicular rash affecting the left forehead, periorbital skin and nose but sparing the tip of the nose. This is known as negative Hutchinson's sign. tion is a useful sign of ocular involvement. If these features are present immediate referral to ophthalmology is needed.

In this case the alae nasae was spared, and the patient denied any eye pain or photophobia. A comprehensive eye examination revealed no evidence of anterior or posterior segment inflammation. The patient was managed with systemic acyclovir and prophylactic topical antibiotic ointment to protect the ocular surface.

\section{Learning points}

- Latent varicella-zoster virus in neurons of cranial and spinal ganglia may reactivate to produce shingles (zoster). A particular predilection for the ophthalmic division of the trigeminal nerve exists.

- A herpes zoster ophthalmicus rash involving the tip of the nose (alae nasae) is known as a positive Hutchinson's sign. This indicates nasociliary nerve involvement; the nasociliary also innervates the eye.

- Involvement of the eye is more common when Hutchinson's sign is positive; however, the eye may still be involved despite a negative Hutchinson's sign. Reduced vision, eye pain, photophobia and reduced corneal sensation are good indicators of eye involvement.

Contributors ASH came up with the idea and wrote the paper in conjunction with JS-I. MT provided a supervisory role.

\section{Competing interests None.}

Patient consent Obtained.

Provenance and peer review Not commissioned; externally peer reviewed.

\section{REFERENCES}

1 Ostler HB, Thygeson P. The ocular manifestations of herpes zoster, varicella, infectious mononucleosis and cytomegalovirus disease. Surv Ophthalmol 1976;21:148.

2 Kleinschmidt-DeMasters BK, Gilden DH. Varicella-Zoster virus infections of the nervous system: clinical and pathologic correlates. Arch Pathol Lab Med 2001;125:770-80.

3 Hutchinson J. A clinical report on herpes zoster frontalis ophthalmicus (shingles affecting the forehead and nose). $R$ Lond Ophthalmic Hosp Rep 1865;5:191--215.

4 Zaal MJ, Völker-Dieben HJ, D'Amaro J. Prognostic value of Hutchinson's sign in acute herpes zoster ophthalmicus. Graefes Arch Clin Exp Ophthalmol 2003;241:187-91. 
Copyright 2014 BMJ Publishing Group. All rights reserved. For permission to reuse any of this content visit http://group.bmj.com/group/rights-licensing/permissions.

BMJ Case Report Fellows may re-use this article for personal use and teaching without any further permission.

Become a Fellow of BMJ Case Reports today and you can:

- Submit as many cases as you like

- Enjoy fast sympathetic peer review and rapid publication of accepted articles

- Access all the published articles

- Re-use any of the published material for personal use and teaching without further permission

For information on Institutional Fellowships contact consortiasales@bmjgroup.com

Visit casereports.bmj.com for more articles like this and to become a Fellow 